\title{
Teaching NeuroImages: Hemimeningitis mimicking acute ischemic stroke
}

Sergio A. Castillo-Torres, MD, and Héctor R. Martínez, MD, PhD, FACP

Neurology ${ }^{\circledR}$ 2018;91:e2280-e2281. doi:10.1212/WNL.0000000000006655
Correspondence

Dr. Castillo-Torres

sergio.castillotr@

uanl.edu.mx

Figure 1 Contrast-enhanced MRI

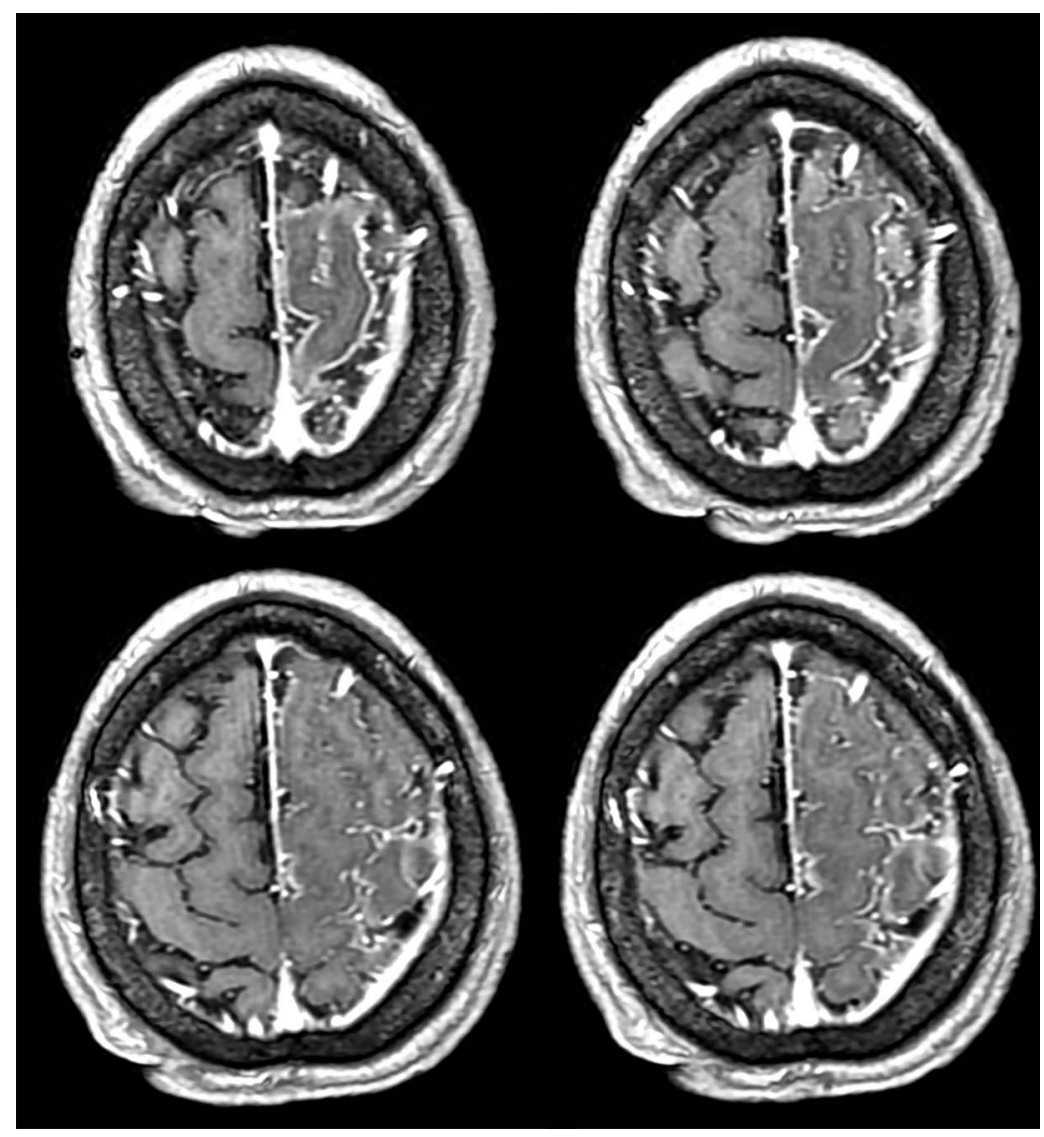

Contrast-enhanced MRI T1 sequence shows localized unilateral meningeal enhancement on superior and middle left frontal gyri.
A 78-year-old man with sudden-onset right-sided weakness and mutism had no history of fever, seizures, or headache. On examination, abulia, transcortical motor aphasia, and right dense hemiplegia were noted. Contrast-enhanced brain MRI suggested meningitis (figure 1) and ruled out stroke (figure 2). On CSF analysis, lymphocytic (94\%) pleocytosis (163 cells $/ \mathrm{mm}^{3}$ ), abundant Gram-positive cocci, and hyperproteinorrachy $(48 \mathrm{mg} / \mathrm{dL})$ with normal CSF:serum glucose ratio were noted. After 14 days of ceftriaxone plus vancomycin and recovery of hemiparesis (MRC 4/5), speech (improved fluency), and CSF-pleocytosis resolution $\left(2\right.$ cells $\left./ \mathrm{mm}^{3}\right)$, the patient was

\section{MORE ONLINE}

$\rightarrow$ Teaching slides

links.lww.com/WNL/

A760 
Figure 2 Noncontrast-enhanced MRI
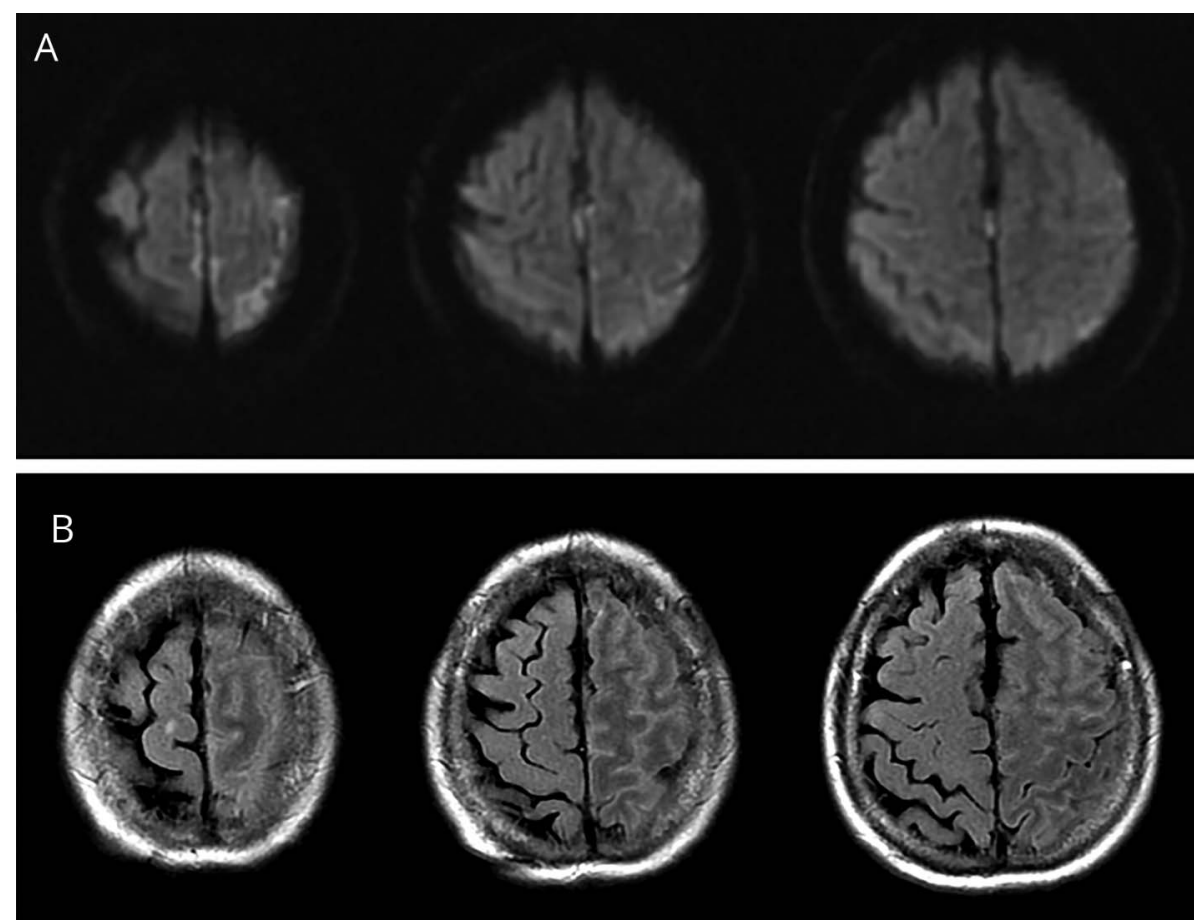

MRI shows axial diffusion-weighted imaging (DWI) (A) and fluid-attenuated inversion recovery (FLAIR) (B) sequences. There is increased FLAIR signal on prefrontal, superior, and middle left frontal gyri, without any corresponding changes on DWI.

discharged. Localized meningitis is rare. We found 2 reports: one stroke mimic ${ }^{1}$ and another associated with necrotizing vasculitis. ${ }^{2}$

\section{Author contributions}

Sergio A. Castillo-Torres: article concept and writing. Héctor R. Martínez: article concept and editing.

\section{Study funding}

No targeted funding reported.

\section{Disclosure}

The authors report no disclosures relevant to the manuscript. Go to Neurology.org/N for full disclosures.

\section{References}

1. Ingolfsdottir HM, Caye-Thomasen P. Stroke? Localized, otogenic meningitis! Scand J Infect Dis 2011;43:392-394.

2. Wingerchuk DM, Dyck PJ, Mertz LE. Hemi-meningitis: a focal sign heralding a multisystem necrotizing vasculitis. Neurology 2008;70:2014 


\section{Neurology}

\section{Teaching NeuroImages: Hemimeningitis mimicking acute ischemic stroke \\ Sergio A. Castillo-Torres and Héctor R. Martínez \\ Neurology 2018;91;e2280-e2281 \\ DOI 10.1212/WNL.0000000000006655}

\section{This information is current as of December 10, 2018}

Updated Information \&

Services

References

Subspecialty Collections

Permissions \& Licensing

Reprints including high resolution figures, can be found at: http://n.neurology.org/content/91/24/e2280.full

This article cites 2 articles, 1 of which you can access for free at: http://n.neurology.org/content/91/24/e2280.full\#ref-list-1

This article, along with others on similar topics, appears in the following collection(s):

All Clinical Neurology

http://n.neurology.org/cgi/collection/all_clinical_neurology Meningitis

http://n.neurology.org/cgi/collection/meningitis

MRI

http://n.neurology.org/cgi/collection/mri

Information about reproducing this article in parts (figures,tables) or in its entirety can be found online at:

http://www.neurology.org/about/about_the_journal\#permissions

Information about ordering reprints can be found online:

http://n.neurology.org/subscribers/advertise

Neurology ${ }^{\circledR}$ is the official journal of the American Academy of Neurology. Published continuously since 1951, it is now a weekly with 48 issues per year. Copyright (O) 2018 American Academy of Neurology. All rights reserved. Print ISSN: 0028-3878. Online ISSN: 1526-632X.

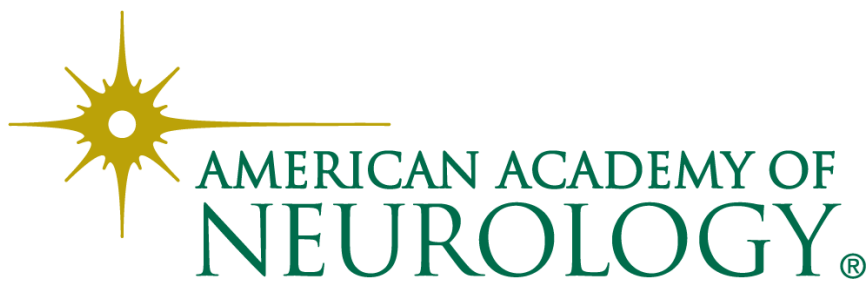

